\title{
Immobilization of ruthenium phthalocyanine on silica-coated multi-wall partially oriented carbon nanotubes: Electrochemical detection of fenitrothion pesticide
}

\author{
Thiago C. Canevari ${ }^{\mathrm{a}, *}$, Thiago M. Prado ${ }^{\mathrm{b}}$, Fernando H. Cincotto ${ }^{\mathrm{b}}$, Sergio A.S. Machado ${ }^{\mathrm{b}}$ \\ a Engineering School, Mackenzie Presbyterian University, 01302-907 São Paulo, SP, Brazil \\ ${ }^{\mathrm{b}}$ Institute of Chemistry, State University of São Paulo, P.O. Box 780, 13560-970 São Carlos, SP, Brazil
}

\section{A R T I C L E I N F O}

\section{Article history:}

Received 10 July 2015

Received in revised form 7 December 2015

Accepted 9 December 2015

Available online 10 December 2015

\section{Keywords:}

Composites

Nanostructures

Sol-gel chemistry

Electrochemical measurements

Catalytic properties

\begin{abstract}
A B S T R A C T
This paper reports on the determination of the pesticide fenitrothion using a glassy carbon electrode modified with silica-coated, multi-walled, partially oriented carbon nanotubes, $\mathrm{SiO}_{2} / \mathrm{MWCNTs}$, containing ruthenium phthalocyanine (RuPc) synthesized in situ. The hybrid $\mathrm{SiO}_{2} / \mathrm{MWCNTs} / \mathrm{RuPc}$ material was characterized by UV-vis absorption spectroscopy, X-ray photoelectron spectroscopy (XPS), scanning electron microscopy (SEM), high-resolution transmission electron microscopy (HR-TEM) and differential pulse voltammetry. The modified electrode showed well-defined peaks in the presence of fenitrothion in acetate buffer, $\mathrm{pH} 4.5$, with a sensitivity of $0.0822 \mu \mathrm{A} \mu \mathrm{M}^{-1} \mathrm{~mm}^{-2}$ and a detection limit of $0.45 \mathrm{ppm}$. Notably, the modified $\mathrm{SiO}_{2} / \mathrm{MWCNTs} / \mathrm{RuPc}$ electrodes with did not suffer from significant influences in the presence of other organophosphorus pesticides during the determination of the fenitrothion pesticide. Moreover, this modified electrode showed excellent performance in the determination of fenitrothion in orange juice.
\end{abstract}

(c) 2015 Elsevier Ltd. All rights reserved.

\section{Introduction}

Pesticides are a class of chemical compounds widely used to combat insects and pests in agriculture and are occasionally employed for the residential pest combat. Despite the fact that only a small quantity of the applied pesticides, less than $0.5 \%$, are actually absorbed by plants, they have a direct influence on the development of ecosystems [1]. It is very important to highlight that most pesticides are water soluble and highly toxic and therefore may indirectly contaminate aquatic organisms and humans.

Among the different classes of existing pesticides [2] organophosphate pesticides (OP) receive a considerable amount of attention as they are commonly used for combating pests in different types of crops and are known to be extremely harmful to the nervous system of humans. It has been reported that the toxicity of organophosphorus pesticides in humans is related to the $\mathrm{P}=\mathrm{O}$ bonds forming adducts with molecules and metabolites [3].

\footnotetext{
* Corresponding author. Fax: +55 1635213109.

E-mail address: tccanevari@gmail.com (T.C. Canevari).
}

Fenitrothion, (O,O-dimethyl O-(3-methyl-4-nitrophenyl) phosphorothioate, is an organophosphate pesticide widely used to combat pests in many countries worldwide [4,5]. Fenitrothion is considered highly toxic and is part of what is known as the 'Red List' of pesticides according to the UK Environmental Agency [6]. Therefore, the quantification of fenitrothion pesticide in the environment and particularly in food is extremely important to help avoid associated health problems for humans.

Different analytical techniques [7-10] that require highly skilled labor and the pre-treatment of samples are sometimes used to quantify fenitrothion. Alternatively, electroanalytical techniques are used, as they do not always require sample pretreatment processes as the pesticide analysis is performed using different types of modified electrodes [11-13].

Based on this contextual background, the development of hybrid materials for use in electrochemical sensors has generated a significant amount of interest due to the possibilities which may be realized from combined elements compared to separate materials $[14,15]$. Among the hybrid materials which have generated significant interest in this regard are materials based on the combination of silica base and carbon allotropes (carbon nanotubes and graphene species), as the resultant hybrid may offer enhanced properties such as robustness, high chemical and 


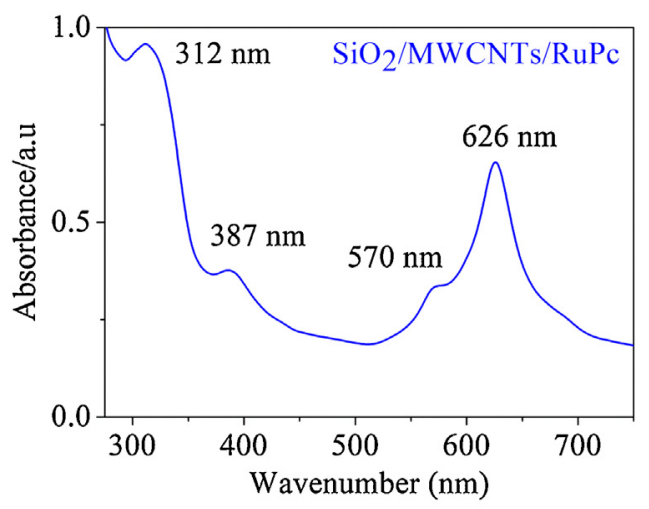

Fig. 1. UV-vis absorption spectrum of $\mathrm{SiO}_{2} / \mathrm{MWCNTs} / \mathrm{RuPc}$ hybrid material in nujol (mineral oil).

mechanical stability, high reactivity due to varied functionality and unique properties related nanoscale structure. The different functional groups offered by these hybrids could facilitate interaction with other species with a view to improving the sensitivity and selectivity of electrochemical sensors.

Metal phthalocyanines (MPc) are macrocyclic compounds with $\pi$ structure which are employed for practical use in several areas [16-21]. In particular, MPc have been used in the development of electrochemical sensors due to their excellent redox properties [22-25]. One MPc that has attracted significant research interest is phthalocyanine ruthenium (RuPc), due to its excellent catalytic properties [26].

With this in mind, this manuscripts reports on the development of an electrochemical sensor with a view to the quantification of fenitrothion in orange juice. The sensor design was based on the initial synthesis of hybrid silica and multi-walled partially oriented carbon nanotubes $\left(\mathrm{SiO}_{2} / \mathrm{MWCNTs}\right)$, which in-turn facilitated the in situ synthesis of phthalocyanine ruthenium.

\section{Experimental}

\subsection{Reagents}

All of the reagents used were of high purity: Multiwalled carbon nanotubes (Aldrich), tetraethyl orthosilicate, Tetraethyl orthosilicate (TEOS) (Aldrich, 98\%); ruthenium acetate (Aldrich), fenitrothion (Aldrich), malathion (Aldrich), chlorpyriphos (Aldrich), ascorbic acid (Aldrich) dimethylformamide (DMF), ethanol (Aldrich 99.9\%) and HF (Synth, 47\%). A $0.1 \mathrm{~mol} \mathrm{~L}^{-1} \mathrm{pH} 4.5$ acetate buffer solution was prepared in ultrapure water. All other aqueous solutions were also prepared with ultrapure water.

\subsection{Preparation of $\mathrm{SiO}_{2} / \mathrm{MWCNTs}$ hybrid material}

The hybrid $\mathrm{SiO}_{2} /$ MWCNTs material, containing $20 \mathrm{wt}$.\% of carbon nanotubes was prepared according to the procedure described in Ref. [27] with some modifications. Briefly, a solution of TEOS $(0.0225 \mathrm{~mol})$ and ethanol $1 / 1(\mathrm{v} / \mathrm{v})$ was prepared and left to mix for 20 min, after which $2 \mathrm{~mL}$ of $\mathrm{H}_{2} \mathrm{O}$ was added and the solution was stirred for a further $5 \mathrm{~min}$. Then, $0.9 \mathrm{~g}$ of multi-walled carbon

Table 1

Summary of binding energy (eV) of Ru $3 d_{5 / 2}, N 1 s, C 1 s, O 1$ s and Si 2 p components of $\mathrm{SiO}_{2} / \mathrm{MWCNTs} / \mathrm{RuPc}$ hybrid material.

\begin{tabular}{llllll}
\hline Sample & $\mathrm{C} 1 \mathrm{~s}$ & $\mathrm{Ru} \mathrm{3d_{5/2 }}$ & $\mathrm{Si} 2 \mathrm{p}$ & $\mathrm{O} \mathrm{1s}$ & N (nitrogen) \\
\hline $\mathrm{SiO}_{2} / \mathrm{MWCNT/RuPc}$ & 285.0 & 279.3 & 103.5 & 530.2 & 397.5 \\
& 287 & 283.1 & - & 532.2 & 399.3 \\
& 289.8 & - & - & 533.7 & 402.2 \\
\hline
\end{tabular}

nanotubes were added to the mixture and the solution was stirred for another $5 \mathrm{~min}$. Finally, $0.5 \mathrm{~mL}$ of hydrofluoric acid (47\%) was added and the mixture was sonicated until gel formation was observed. The fresh gel was left to rest for 10 days at room temperature to complete the sol-gel process. After this time, the formed xerogel was finely ground and the powder was washed with ethanol in a Soxhlet extractor for $1.5 \mathrm{~h}$, before being subjected to heat treatment at 323 .

Then, the hybrid $\mathrm{SiO}_{2} /$ MWCNTs material was subjected to acid treatment by dispersion in a $1: 3$ acid solution of $\mathrm{H}_{2} \mathrm{SO}_{4} / \mathrm{HNO}_{3}$ followed by reflux for $12 \mathrm{~h}$. This type of acid treatment promotes the formation of functional groups, namely carboxyl, hydroxyl and ester groups, which would favor the incorporation of other species on the surface of the carbon nanotubes.

\subsection{In situ synthesis of ruthenium phthalocyanine on the $\mathrm{SiO}_{2} /$ MWCNTs hybrid material}

The ruthenium phthalocyanine (RuPc) was synthesized in situ on the previously functionalized hybrid material according to the following procedure: [28] $1 \mathrm{~g}$ of the hybrid material $\left(\mathrm{SiO}_{2}\right)$ MWCNTs) was dispersed in $10 \mathrm{~mL}$ of aqueous ruthenium acetate $\left(1 \times 10^{-3} \mathrm{~mol} \mathrm{~L}^{-1}\right)$ and placed in a water bath set to $363 \mathrm{~K}$, until complete evaporation of the solvent was achieved. This step serves to incorporate the ruthenium in the $\mathrm{SiO}_{2} / \mathrm{MWCNTs}$ through associations with the silanol groups and even more so with carbon nanotubes, due to their higher functionality. These functional groups favor ion exchange reactions with the ruthenium acetate and form $\mathrm{SiO}_{2} / \mathrm{MWCNTs} / \mathrm{Ru}$. Then, $500 \mathrm{mg}$ of the newly formed $\mathrm{SiO}_{2} / \mathrm{MWCNTs} / \mathrm{Ru}$ was mechanically mixed with phthalonitrile in a 1:4 ratio. This mixture was placed in a glass ampoule which was submerged in a $473 \mathrm{~K}$ silicone bath for $2 \mathrm{~h}$ under slow rotation. These conditions led to the condensation of phthalonitrile and the formation of ruthenium phthalocyanine (RuPc). The newly formed ruthenium phthalocyanine, named $\mathrm{SiO}_{2} / \mathrm{MWCNTs} / \mathrm{RuPc}$, was then washed with ethanol in a Soxhlet extraction system to remove any residual phthalocyanine that had not adsorbed on the material.

\subsection{Preparation of the modified glassy carbon electrode}

The glassy carbon electrodes (GCEs) were subjected to electrochemical treatment prior to surface modification, which consisted of several cyclic voltammetry measurements in $0.1 \mathrm{M}$ $\mathrm{H}_{2} \mathrm{SO}_{4}$ over the potential range of $-0.5-1 \mathrm{~V}$. Then, modification of the electrodes was achieved by adsorbing a film from a dimethylformamide (DMF) solution which contained $1 \mathrm{mg} / \mathrm{mL}$ hybrid materials of $\mathrm{SiO}_{2} / \mathrm{MWCNTs}$ or $\mathrm{SiO}_{2} / \mathrm{MWCNTs} / \mathrm{RuPc}$. The films (either $\mathrm{SiO}_{2} / \mathrm{MWCNTs}$ or $\mathrm{SiO}_{2} / \mathrm{MWCNTs} / \mathrm{RuPc}$ ) were prepared by the addition of a $9 \mu \mathrm{L}$ drop of the DMF solution onto the electrode surface followed by solvent evaporation over approximately $4 \mathrm{~h}$ at room temperature.

\subsection{Apparatus}

The UV/vis spectrum of $\mathrm{SiO}_{2} / \mathrm{MWCNTs/RuPc}$ was obtained from a JASCO spectrophotometer. The hybrid material containing ruthenium phthalocyanine in powder form was dispersed in mineral oil (Nujol) and the mixture was placed between two quartz plates.

XPS was performed in a VSW HA 100 spectrometer equipped with a hemispherical electron analyzer, using an Al anode as the $\mathrm{X}$-ray source. The correction of the binding energies for charge was obtained using the reference Si 2p line from silica.

Field emission gun scanning electron microscopy (FEG-SEM) of $\mathrm{SiO}_{2} / \mathrm{MWCNTs} / \mathrm{RuPc}$ was performed in a FEI 
a)

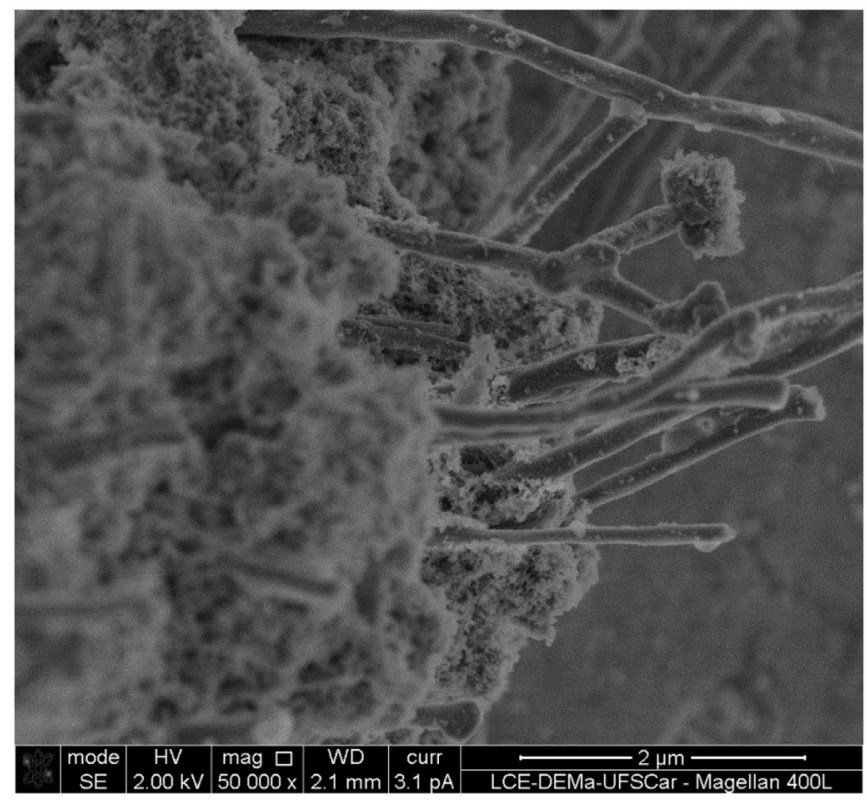

b)

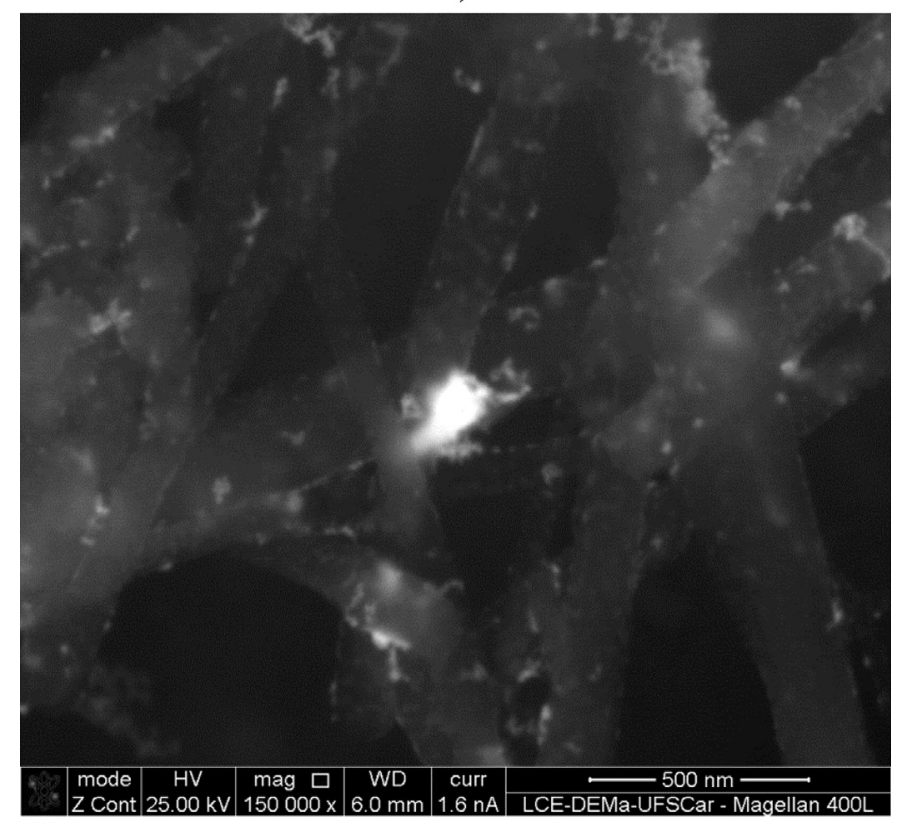

Fig. 2. (a) SEM image of $\mathrm{SiO}_{2} / \mathrm{MWCNTs} / \mathrm{RuPc}$ hybrid material obtained by secondary electrons and (b) SEM image of $\mathrm{SiO}_{2} /$ MWCNTs/RuPc hybrid material obtained by backscattering electrons.

Magellan-400 microscope equipped with a high-resolution secondary electron and backscattering detector.

High resolution transmission electron microscopy (HR-TEM) was realized by a FEI TECNAI $G^{2}$ F20 microscope operating at $200 \mathrm{kV}$.

The electrochemical measurements were performed in a potentiostat-galvanostat (PGSTAT-302 model) using a conventional electrochemical cell with a working electrode, reference electrode $(\mathrm{Ag} / \mathrm{AgCl})$ and counter electrode $(\mathrm{Pt})$ in acetate buffer $0.1 \mathrm{~mol} \mathrm{~L}^{-1}, \mathrm{pH} 4.5$, at room temperature. All measurements were conducted under an inert atmosphere.

\section{Results}

3.1. Spectroscopic characterization of the $\mathrm{SiO}_{2} / \mathrm{MWCNTs} / \mathrm{RuPc}$ hybrid material

The UV-vis spectrum of the hybrid material containing ruthenium phthalocyanine $\left(\mathrm{SiO}_{2} / \mathrm{MWCNTs} / \mathrm{RuPc}\right)$ was obtained to confirm the formation of ruthenium phthalocyanine and to also show the interaction between the phthalocyanine hybrid material and $\mathrm{SiO}_{2} / \mathrm{MWCNTs}$, which can be observed from the existence of $\mathrm{B}$ (Soret) and Q bands (Fig. 1).

The B band usually appears between $300 \mathrm{~nm}$ and $350 \mathrm{~nm}$ depending on the type phthalocyanine formed as well as the type of solvent $[29,30]$. The band B (Soret) refers to electron transfer between the frontier HOMO-LUMO orbitals and the aromatic structure of phthalocyanine, i.e. between the orbitals with symmetry $a_{2} u$ and eg [31]. The Q-band, which is usually accompanied by a vibrational component, occurs between 500 and $720 \mathrm{~nm}$ [32]. This Q-band refers to the electronic transition between orbitals $a_{1} u$ and $e g$. Thus, the formation of ruthenium phthalocyanine (RuPc) in the hybrid material $\mathrm{SiO}_{2} /$ MWCNTs is confirmed by the presence of the $B$ bands around $312 \mathrm{~nm}$ and the $\mathrm{Q}$ band around $626 \mathrm{~nm}$. The band which appears at $570 \mathrm{~nm}$ is related to the vibrational component of the Q-band (due to charge transfer processes, and dimer formation) and the band that appears at $348 \mathrm{~nm}$ is most likely due to the $\pi-\pi$ interactions between the $\mathrm{SiO}_{2} / \mathrm{MWCNT}$ hybrid and RuPc [33-35].

The chemical composition of the hybrid material $\mathrm{SiO}_{2} / \mathrm{MWCNTs}$ containing ruthenium phthalocyanine (RuPc) and the nature of the chemical bonds were studied by X-ray photoelectron spectroscopy (XPS). Table 1 shows the binding energy (BE) values of the components Ru $3 d_{5 / 2}, N 1 s, C 1 s, O 1 s$ and Si 2p, obtained from the deconvolution of the spectra (Supplementary data).

The binding energy value for the Ru $3 \mathrm{~d}$ component at around $279.3 \mathrm{eV}$ is indicative of the presence of ruthenium atoms in the $\mathrm{Ru}$ (II) oxidation state. Compared with free ruthenium phthalocyanine (BE of approximately $281 \mathrm{eV}$ ), the ruthenium phthalocyanine hybrid material prepared in $\mathrm{SiO}_{2} / \mathrm{MWCNTs}$ has a lower BE value, possibly due to electron transfer between the MWCNTs and RuPc. The other binding energy value recorded for the Ru 3d component at around $283.1 \mathrm{eV}$, is probably due to the presence of small amounts $\mathrm{Ru}(\mathrm{IV})$ [36].

The $\mathrm{N}$ 1s component displays three different binding energy values of $397.5,399.3$ and $402.2 \mathrm{eV}$. The BE observed around $397.5 \mathrm{eV}$ corresponds to the $\mathrm{C}-\mathrm{N}$ bond of the phthalocyanine pyridine ring, the $\mathrm{BE}$ at approximately $399.3 \mathrm{eV}$ most likely corresponds to the $\mathrm{N}$ of the pyrrole ring and the energy observed at $402.2 \mathrm{eV}$ can be assigned to $\mathrm{N}=\mathrm{C}$ double bonds in the structure of phthalocyanine [37,38].

The carbon spectrum deconvolution showed different binding energy values for the component $\mathrm{C} 1 \mathrm{~s}$. These different BE values correspond to different functional groups on the carbon nanotubes, which formed mainly due to the exposure of $\mathrm{SiO}_{2} / \mathrm{MWCNTs}$ to acid treatment $\left(\mathrm{HNO}_{3} / \mathrm{H}_{2} \mathrm{SO}_{4}\right)$ during the preparation steps. The $\mathrm{BE}$ observed at $285.0 \mathrm{eV}$ can be assigned to the presence of $\mathrm{sp}^{2}$ carbon from aromatic poly structures and the presence of $\mathrm{sp}^{3}$ carbon in the aliphatic structures. The BE at approximately $287 \mathrm{eV}$ corresponds to the quinone $\mathrm{C}=\mathrm{O}$ groups and the peak observed at approximately $289.8 \mathrm{eV}$ corresponds to $\mathrm{C}-\mathrm{OO}^{-}$from carboxylic and ester group [39]. We hypothesize that the differences observed for the $\mathrm{C} 1 \mathrm{~s} \mathrm{BE}$ is due to synergistic effects between the MWCNTs, $\mathrm{SiO}_{2}$ and ruthenium phthalocyanine.

Deconvoluted oxygen spectra also displayed different binding energy values for the $\mathrm{O} 1 \mathrm{~s}$ component. These different $\mathrm{BE}$ values observed at around $530.2 \mathrm{eV}, 532.2 \mathrm{eV}$ and $533.7 \mathrm{eV}$ correspond to oxygen being present in a variety of chemical environments, 
a)

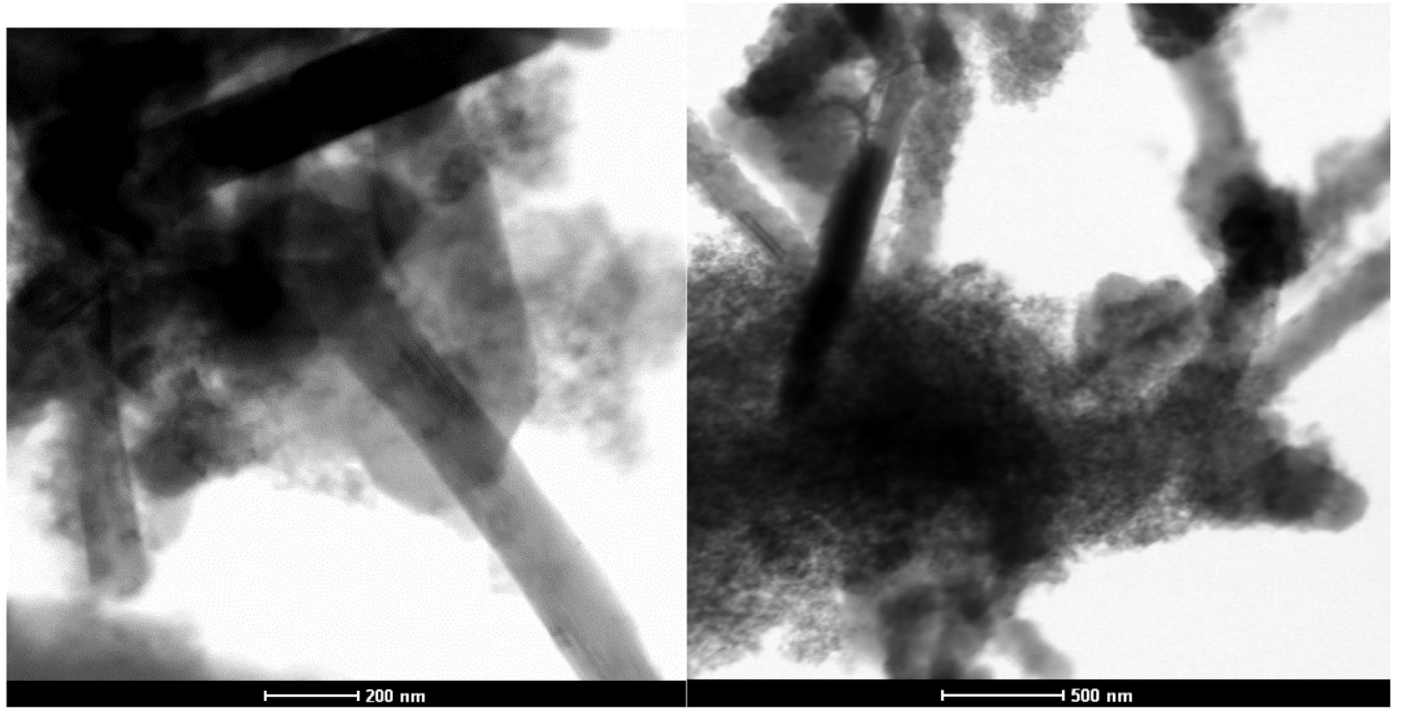

b)

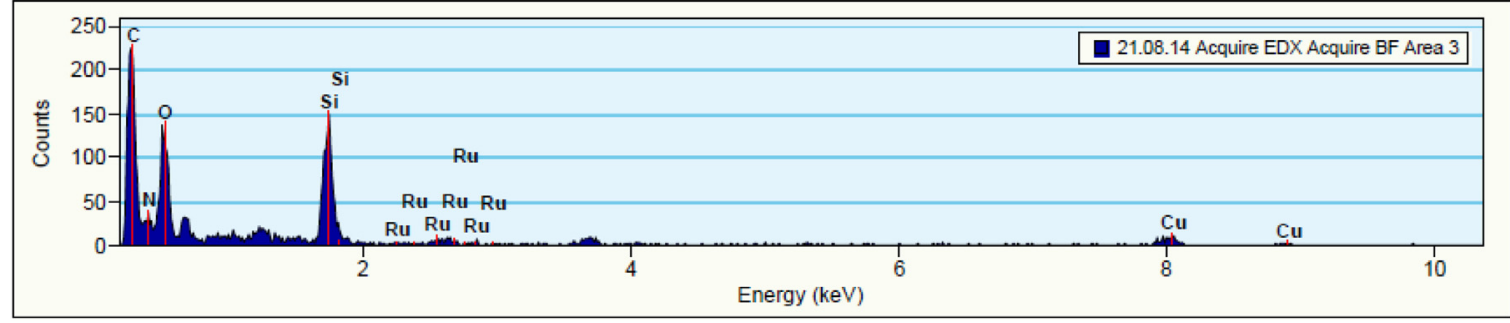

Fig. 3. (a) HR-TEM micrographs with different size and (b) EDX spectrum of $\mathrm{SiO}_{2} / \mathrm{MWCNTs} / \mathrm{RuPc}$ hybrid material.

which in-turn confirms the presence of different functional groups, such as hydroxyl (-OH), esters and anhydrides [39]. The presence of these oxygen containing functional groups can be attributed to the acid treatment given during hybrid material preparation.

The BE of the $\mathrm{Si} 2 \mathrm{p}$ seen at $103.5 \mathrm{eV}$ is indicative of the formation of silica

\subsection{SEM and HR-TEM analyses}

The morphological study of the hybrid material containing ruthenium phthalocyanine, $\mathrm{SiO}_{2} / \mathrm{MWCNTs} / \mathrm{RuPc}$, was carried out through scanning electron microscopy (SEM) using secondary electrons (Fig. 2a) and backscattered electrons (Fig. 2b).

Fig. 2a shows that MWCNTs that were physically incorporated into the silica matrix were partially oriented. This orientation makes the highly reactive nanotube ends more available than if they were randomly distributed, which in-turn favors the anchorage of ruthenium phthalocyanine. The partial orientation should contribute to a significant improvement in the electrochemical properties of the hybrid material. Fig. $2 \mathrm{~b}$, obtained using backscattered electrons, shows the differences observed in the composition of the $\mathrm{SiO}_{2} / \mathrm{MWCNTs} / \mathrm{RuPc}$ hybrid material. The very bright dots, which point to the presence of ruthenium phthalocyanine, can be clearly observed throughout the material, especially on the carbon nanotubes. Ruthenium phthalocyanine shines comparatively bright as ruthenium atoms have the highest atomic number compared to the other elements present in the hybrid, and thus absorb larger amounts of radiation.
The micrographs shown in Fig. 3a and b show the microstructure of the hybrid material obtained using HR-TEM in bright field and dark field and the associated energy dispersive X-ray spectrum (EDX). As can be seen, the HR-TEM micrographs and EDX analysis confirmed the incorporation of MWCNTs in the silica matrix and the formation of the ruthenium phthalocyanine in the hybrid $\mathrm{SiO}_{2} /$ MWCNTs material, which is consistent with the SEM images. The copper peak observed in the EDX spectrum is due to the copper grid used in HR-TEM analyses.

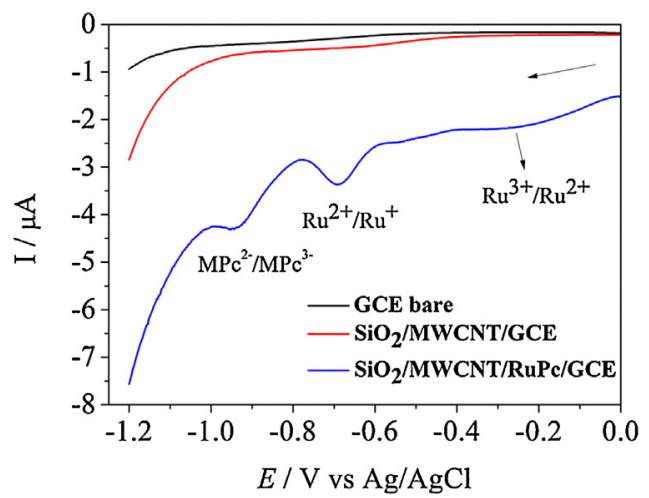

Fig. 4. Differential pulse voltammograms of the glassy carbon electrode (GCE), the $\mathrm{SiO}_{2} / \mathrm{MWCNTs}$ modified electrode and the $\mathrm{SiO}_{2} / \mathrm{MWCNTs} / \mathrm{RuPc}$ modified electrode in $0.1 \mathrm{M}$ acetate buffer ( $\mathrm{pH} 4.5$ ); potential range to $0 \mathrm{~V}$ to $-1.2 \mathrm{~V}$, scan rate $20 \mathrm{mV} \mathrm{s}^{-1}$. 
a)

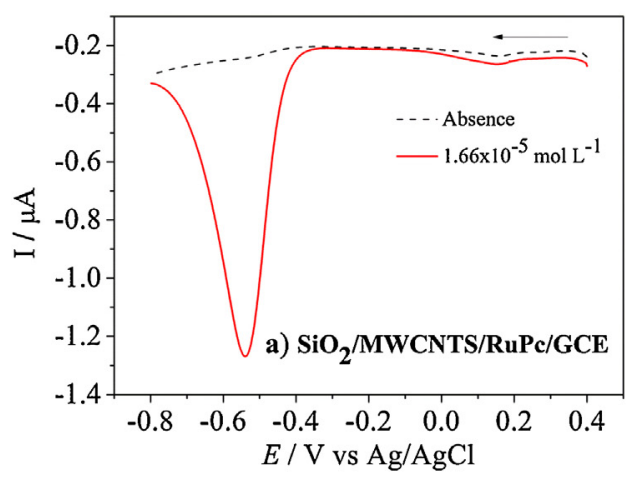

b)

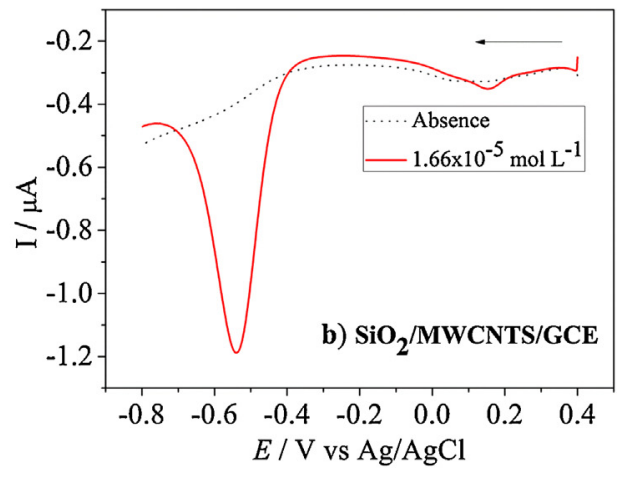

c)

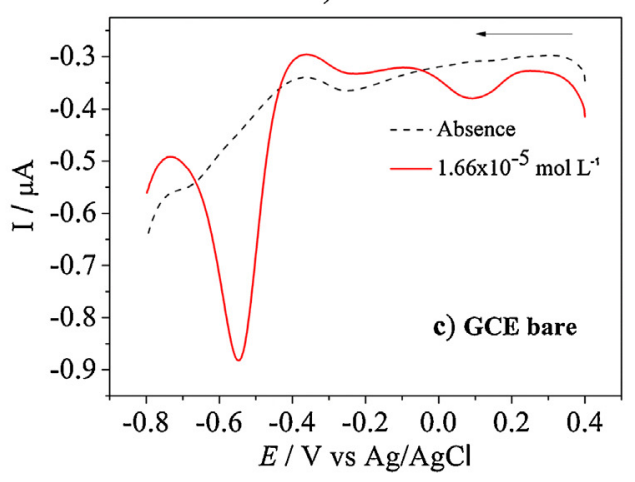

Fig. 5. Electrocatalytic study of fenitrothion pesticide using the (a) $\mathrm{SiO}_{2} / \mathrm{MWCNTs} /$ RuPc/GCE electrode (b) $\mathrm{SiO}_{2}$ /MWCNTs/GCE electrode and (c) GCE electrode using differential pulse voltammetry in $0.1 \mathrm{M}$ acetate buffer $(\mathrm{pH} 4.5)$ and a scan rate of $20 \mathrm{mV} \mathrm{s}^{-1}$.

\subsection{Electrochemical characterization of $\mathrm{SiO}_{2} / \mathrm{MWCNTs} / \mathrm{RuPc}$}

Fig. 4 shows the differential pulse voltammograms obtained for the modified $\mathrm{SiO}_{2} / \mathrm{MWCNT} / \mathrm{RuPc}, \mathrm{SiO}_{2} / \mathrm{MWCNTs}$ and bare GCE electrodes. The measurements were performed in acetate buffer, $\mathrm{pH} 4.5$, in an inert atmosphere. As can be seen, only the glassy carbon electrode modified with $\mathrm{SiO}_{2} / \mathrm{MWCNTs} / \mathrm{RuPc}$ presented three reduction processes at different potentials. Cathodic potentials around $E_{\mathrm{red} 1}=-0.23 \mathrm{~V}, E_{\mathrm{red} 2}=-0.69 \mathrm{~V}$ and $E_{\mathrm{red} 3}=-0944$ $\mathrm{V}$ can be respectively assigned to the cathodic processes of $\mathrm{Ru}^{3}$ ${ }^{+} / \mathrm{Ru}^{2+}, \mathrm{Ru}^{2+} / \mathrm{Ru}^{1+}$ and $\mathrm{MPc}^{2-} / \mathrm{MPc}^{3-}[40,41]$. The potentials measured for RuPc synthesized in $\mathrm{SiO}_{2}$ /MWCNTs in acetate buffer, $\mathrm{pH} 4.5$ are somewhat different from those presented by RuPc in phosphate buffer. This can be attributed to the synergic relationship between $\mathrm{SiO}_{2}$ /MWCNTs and RuPc and the fact that the RuPc

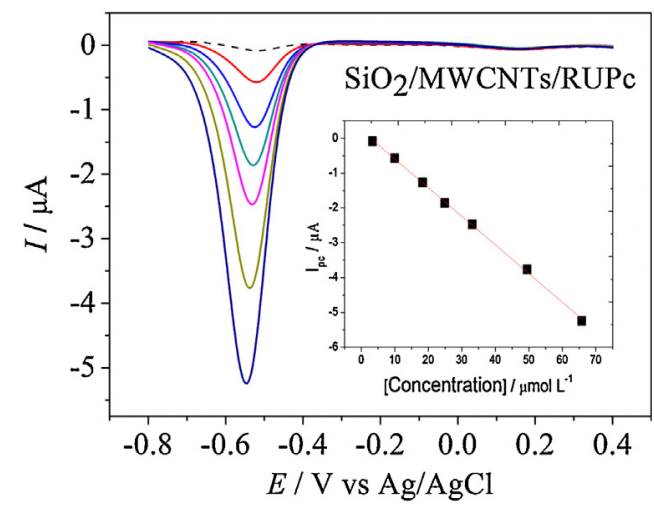

Fig. 6. Electrochemical determination of fenitrothion pesticide by differential pulse voltammetry in acetate buffer, pH 4.5 using $\mathrm{SiO}_{2} / \mathrm{MWCNTs} / \mathrm{RuPc} / \mathrm{GCE}$. Measurements were obtained under an inert atmosphere at a scan rate of $20 \mathrm{mV} \mathrm{s}^{-1}$. Inset figure: calibration curve I versus fenitrothion concentration.

potential is directly influenced by the solvent type and variations in $\mathrm{pH}[40]$.

The electrocatalytic activity of the $\mathrm{SiO}_{2} / \mathrm{MWCNTs} / \mathrm{RuPc} / \mathrm{GCE}$ modified electrode for the determination of the pesticide fenitrothion was studied in comparison to the modified $\mathrm{SiO}_{2} /$ MWCNTs/GCE and bare GCE electrodes (Fig. 5). As can be seen, all electrodes showed electrocatalytic activity related to the pesticide fenitrothion, with very similar potentials recorded for the three electrode types: $\mathrm{SiO}_{2} / \mathrm{MWCNTs} / \mathrm{RuPc} / \mathrm{GCE}\left(E_{\mathrm{red}}=-0.54 \mathrm{~V}\right), \mathrm{SiO}_{2} /$ MWCNTs/GCE $\left(E_{\text {red }}=-0.58 \mathrm{~V}\right)$ and bare GCE $\left(E_{\text {red }}=-0.55 \mathrm{~V}\right)$. However, the modified $\mathrm{SiO}_{2} / \mathrm{MWCNTs} / \mathrm{RuPc} / \mathrm{GCE}$ electrode (Fig. 5a) shows a better electrocatalytic response than the modified $\mathrm{SiO}_{2} / \mathrm{MWCNTs} / \mathrm{GCE}$ (Fig. 5b) and bare GCE electrodes (Fig. 5c), as can be seen by the current increase upon the addition of $1.66 \times 10^{-5} \mathrm{~mol} \mathrm{~L}^{-1}$ fenitrothion. The difference in the current intensity upon addition of the pesticide fenitrothion between the $\mathrm{SiO}_{2} / \mathrm{MWCNTs} / \mathrm{RuPc} / \mathrm{GCE}$ and $\mathrm{SiO}_{2} / \mathrm{MWCNTs} / \mathrm{GCE}$ electrodes proves that ruthenium phthalocyanine improves the electrocatalytic activity of the hybrid material in relation to fenitrothion determination, due to the increased active area of the modified electrode. The increase in the active improves the electron transfer process at the electrode-solution interface and, thereby, increases the sensitivity.

\subsection{Determination of fenitrothion}

Fig. 6 shows the determination of fenitrothion pesticide by differential pulse voltammetry using a $\mathrm{SiO}_{2} / \mathrm{MWCNTs} / \mathrm{RuPc} / \mathrm{GCE}$ electrode in $0.1 \mathrm{M}$ acetate buffer, $\mathrm{pH}$ 4.5. The reduction current

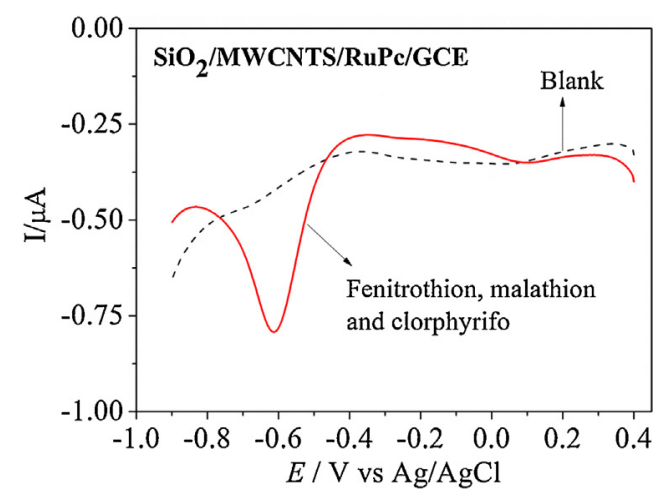

Fig. 7. Interference study of fenitrothion determination in the presence of chlorpyrifos and malathion pesticides in acetate buffer $\mathrm{pH} 4.5$ and an inert atmosphere. 


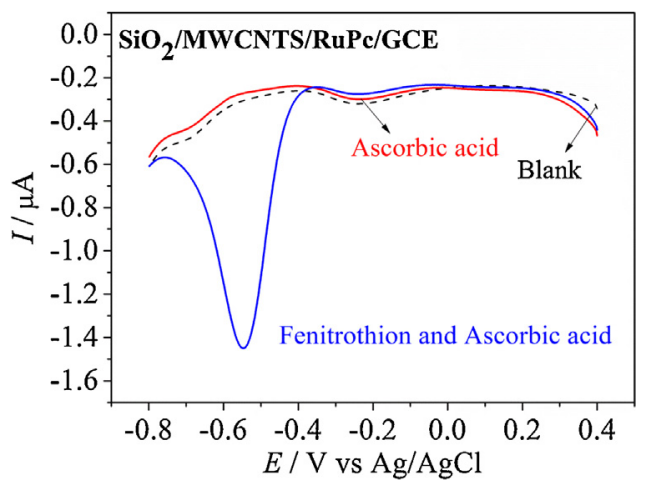

Fig. 8. Fenitrothion determination in the presence of ascorbic acid (AA) in acetate buffer $\mathrm{pH} 4.5$ and an inert atmosphere.

peak increased proportionally with an increasing concentration of fenitrothion. The study was conducted over a pesticide concentration range of $3 \times 10^{-6}-6.6 \times 10^{-5} \mathrm{~mol} \mathrm{~L}^{-1}$, indicating that the $\mathrm{SiO}_{2} /$ MWCNTs/RuPc/GCE electrode can be used for the determination of fenitrothion. The analytical curves of current $(I)$ versus fenitrothion concentration show that cathodic peak currents were linearly proportional to increases in the fenitrothion concentration (inset Fig. 6). This relationship can be expressed by the linear equation $I$ $(\mu \mathrm{A})=0.2245-0.0822 \quad$ [fenitrothion] $/ \mu \mathrm{mol} \mathrm{L}^{-1}$, with linearity $R^{2}=0.9992$ and where $n=7$.

The limit of detection (LOD) was calculated using a $3 \sigma /$ slope ratio, performed according to IUPAC recommendations (where $\sigma$ is the standard deviation in the mean current for 10 differential pulse voltammograms of the blank), and was $1.62 \mu \mathrm{mol} \mathrm{L}^{-1}(0.45 \mathrm{ppm})$. According to Codex Alimentarius [5] the maximum residue limit (MRL) for fenitrothion in fruits is $3.61 \mu \mathrm{mol} \mathrm{L}^{-1}$ (approximately $1 \mathrm{ppm})$. Therefore, the $\mathrm{SiO}_{2} / \mathrm{MWCNTs} / \mathrm{RuPc} / \mathrm{GCE}$ has a LOD compatible with the MRL of fenitrothion in fruit samples.

Furthermore, another distinguishable factor between the $\mathrm{SiO}_{2} /$ MWCNTs/RuPc/GCE modified electrode and the $\mathrm{SiO}_{2} / \mathrm{MWCNTs/}$ GCE electrode is that the $\mathrm{SiO}_{2} / \mathrm{MWCNTs} / \mathrm{GCE}$ electrode shows rapid saturation of its surface when successive additions of fenitrothion pesticide are added (Fig. not shown). This possibly occurs due to the interaction of pesticide with functional groups present in MWCNTs. This fact further confirms that the electrode containing $\operatorname{RuPc}\left(\mathrm{SiO}_{2} / \mathrm{MWCNTs} / \mathrm{RuPc} / \mathrm{GCE}\right)$ is better and more efficient than the $\mathrm{SiO}_{2} / \mathrm{MWCNTs} / \mathrm{GCE}$ electrode for the determination of the pesticide fenitrothion.

\subsection{Interference study}

The versatility of the modified electrode containing $\operatorname{RuPc}\left(\mathrm{SiO}_{2} /\right.$ MWCNTs/RuPc/GCE) for the determination of fenitrothion also was studied. This study was conducted using the differential pulse voltammetry technique in $0.1 \mathrm{~mol} \mathrm{~L}^{-1}$, pH 4.5 acetate buffer under an inert atmosphere, using a concentration of $9.98 \times 10^{-6} \mathrm{~mol} \mathrm{~L}^{-1}$ fenitrothion in the presence of the organophosphate pesticides malathion and chlorpyrifos (for both $C=3.1 \times 10^{-4} \mathrm{~mol} \mathrm{~L}^{-1}$ ). As can be seen in Fig. 7, the pesticides malathion and chlorpyrifos did not exhibit any electrocatalytic response in the potential range studied.

Table 2

Recovery of fenitrothion pesticide in orange juice.

\begin{tabular}{rcc}
\hline Fenitrothion added $\left(\mu \mathrm{mol} \mathrm{L}^{-1}\right)$ & $\begin{array}{l}\text { Fenitrothion found } \\
\left(\mu \mathrm{mol} \mathrm{L}^{-1}\right)\end{array}$ & Recovery $(\%)$ \\
\hline 6.66 & 6.10 & 91.6 \\
13.33 & 12.79 & 96.0 \\
20.00 & 19.76 & 98.8 \\
26.66 & 24.98 & 93.7 \\
\hline
\end{tabular}

This indicates that both of the pesticides, malathion and chlorpyrifos, did not significantly interfere with the determination of fenitrothion.

The possible influence of ascorbic acid (AA) on the determination of fenitrothion was also studied as $A A$ is the main component of orange juice. As can be seen in Fig. 8 , AA $\left(C=4 \times 10^{-4} \mathrm{~mol} \mathrm{~L}^{-1}\right)$ had no electrochemical response in the potential range studied, and thus does not interfere significantly in the determination of pesticide fenitrothion $\left(C=2 \times 10^{-5} \mathrm{~mol} \mathrm{~L}^{-1}\right)$.

From the results reported here, it can be concluded that the $\mathrm{SiO}_{2} /$ MWCNTs/RuPc/GCE modified electrode is an efficient tool to determine fenitrothion and could be used to detect fenitrothion in real samples.

\subsection{Orange juice analysis}

Quantification of the pesticide fenitrothion in orange juice was performed to evaluate the application of $\mathrm{SiO}_{2} / \mathrm{MWCNTs} / \mathrm{RuPc} / \mathrm{GCE}$ electrode in real analysis. In this study, the determination of fenitrothion in orange juice was performed in triplicate, without any pre-treatment procedure. A $10 \mathrm{~mL}$ aliquot of orange juice, obtained from fresh fruits, was added to the electrochemical cell. No electroanalytical signals were observed in the potential range studied (figure not shown), which could be explained either by the absence of fenitrothion in the orange juice samples or that the fenitrothion present was below the detection limit of the electrode. After spiking the orange juice samples with known concentrations of fenitrothion pesticide, it was observed that the peak reduction currents showed a direct relationship with the fenitrothion concentration present in the orange juice. The amount of fenitrothion in the spiked orange juice samples were determined by the calibration method and the results are summarized in Table 2.

The data suggest that the proposed $\mathrm{SiO}_{2} / \mathrm{MWCNTs} / \mathrm{RuPc} / \mathrm{GCE}$ electrode is efficient and could be used to determine fenitrothion in real samples.

\subsection{Reproducibility of measurements with the $\mathrm{SiO}_{2} / \mathrm{MWCNTs} / \mathrm{RuPc} /$ GCE electrode}

The reproducibility and repeatability of measurements taken by the $\mathrm{SiO}_{2} / \mathrm{MWCNTs} / \mathrm{RuPc} / \mathrm{GCE}$ electrode were tested by differential pulse voltammetry using a model concentration of $16.6 \mu \mathrm{mol} \mathrm{L}^{-1}$ fenitrothion pesticide in $0.1 \mathrm{M}$ buffer acetate $(\mathrm{pH} 4.5)$. The measurements were performed ten times with the same electrode, with five different sensors prepared at room temperature, under the same conditions, on different days.

The results indicate that the $\mathrm{SiO}_{2} / \mathrm{MWCNTs} / \mathrm{RuPc} / \mathrm{GCE}$ electrode exhibits good reproducibility and good repeatability without any significant loss of electrocatalytic activity, with a relative standard deviation (RSD) of $2.3 \%$ and $2.4 \%$, respectively.

\section{Conclusion}

The formation of ruthenium phthalocyanine in the hybrid material, $\mathrm{SiO}_{2} / \mathrm{MWCNT}$, was confirmed by UV-vis absorption spectroscopy and X-ray photoelectron spectroscopy (XPS). The glassy carbon electrode modified with $\mathrm{SiO}_{2} / \mathrm{MWCNTs} / \mathrm{RuPc}$ showed excellent electrocatalytic activity, in terms of the determination of the pesticide fenitrothion, compared to the modified $\mathrm{SiO}_{2} / \mathrm{MWCNTs}$ electrode and bare GCE. Moreover, the $\mathrm{SiO}_{2} /$ MWCNTs/RuPc electrode showed high sensitivity and selectivity for the determination of fenitrothion in the presence of other organophosphate pesticides. Therefore, the synergistic effects between silica, MWCNTs and RuPc render the developed hybrid material potentially useful for the development of an 
electrochemical sensor for the determination of fenitrothion in real samples.

\section{Conflict of interest}

The authors declare that they have no conflict of interest.

\section{Acknowledgments}

The authors are the grateful to FAPESP (2011/23047-7 and 2012/ 18339-1) and CNPq for financial support.

\section{Appendix A. Supplementary data}

Supplementary data associated with this article can be found, in the online version, at http://dx.doi.org/10.1016/j. materresbull.2015.12.007.

\section{References}

[1] D. Pimentel, J. Agric. Environ. Ethic. 8 (1995) 17-29.

[2] E.M. Garrido, C. Delerue-Matos, J.L.F.C. Lima, A.M.O. Brett, Anal. Lett. 37 (2004) $1755-1791$.

[3] A.Q. Chen, D. Du, Y.H. Lin, Environ. Sci. Technol. 46 (2012) 1828-1833.

[4] H. Tamura, S.C. Maness, K. Reischmann, D.C. Dorman, L.E. Gray, K.W. Gaido, Toxicol. Sci. 60 (2001) 56-62.

[5] FAO, Analysis of Pesticide Residues, Rome, www.codexalimentarius.net/ pestres/data/pesticides/details.html?id=37 (2013).

[6] A.D. Southam, A. Lange, A. Hines, E.M. Hill, Y. Katsu, T. Iguchi, C.R. Tyler, M.R. Viant, Environ. Sci. Technol. 45 (2011) 3759-3767.

[7] T. Otake, T. Yarita, Y. Aoyagi, Y. Kuroda, M. Numata, H. Iwata, K. Mizukoshi, M. Nakamura, M. Watai, H. Mitsuda, T. Fujikawa, H. Ota, J. Agric. Food Chem. 59 (2011) 8568-8574.

[8] P. Soisungnoen, R. Burakham, S. Srijaranai, Talanta 98 (2012) 62-68.

[9] T. Yarita, T. Otake, Y. Aoyagi, Y. Kuroda, M. Numata, H. Iwata, M. Watai, H. Mitsuda, T. Fujikawa, H. Ota, Talanta 119 (2014) 255-261.

[10] S.K. Cho, A.M. Abd El-Aty, M.M. Rahman, J.H. Choi, J.H. Shim, Food Chem. 165 (2014) 532-539.

[11] L.J. Zhao, F.Q. Zhao, B.Z. Zeng, Biosens. Bioelectron. 62 (2014) 19-24.
[12] A. Kumaravel, M. Chandrasekaran, J. Electroanal. Chem. 650 (2011) 163-170.

[13] G.D. Liu, Y.H. Lin, Anal. Chem. 77 (2005) 5894-5901.

[14] D.R. Kauffman, A. Star, Analyst 135 (2010) 2790-2797.

[15] Y. Park, R.C. Advincula, Chem. Mater. 23 (2011) 4273-4294.

[16] F. Wang, G.J. Wang, H.J. Cui, W.T. Sun, T.B. Wang, Mater. Res. Bull. 63 (2015) $181-186$.

[17] B. Li, X. Zhou, X. Wang, B. Liu, B. Li, J. Power Sources 272 (2014) 320-327.

[18] E.N. Kaya, M. Durmus, M. Bulut, J. Organomet. Chem. 774 (2014) 94-100.

[19] S. Kumar, P. Kumar, S.L. Jain, J. Mater. Chem. A 2 (2014) 18861-18866.

[20] Y. Bernhard, P. Winckler, R. Chassagnon, P. Richard, E. Gigot, J.M.P. Cornetb, R.A. Decre'au, ChemComm 50 (2014) 13975-13978.

[21] W. Mekprasart, N. Vittayakorn, W. Pecharapa, Mater. Res. Bull. 47 (2012) 3114-3119.

[22] P. Li, Y. Ding, A. Wang, L. Zhou, S.H. Wei, Y.M. Zhou, Y.W. Tang, Y. Chen, C.M. Cai, T.H. Lu, ACS Appl. Mater. Interfaces 5 (2013) 2255-2260.

[23] A.C. Boni, A. Wong, R.A.F. Dutra, M.D.T. Sotomayor, Talanta 85 (2011) 2067-2073.

[24] S.B.A. Barros, A. Rahim, A.A. Tanaka, L.T. Arenas, R. Landers, Y. Gushikem, Electrochim. Acta 87 (2013) 140-147.

[25] J.H. Zagal, S. Griveau, J.F. Silva, T. Nyokong, F. Bedioui, Coord. Chem. Rev. 254 (2010) 2755-2791.

[26] M. Ebadi, Can. J. Chem. 81 (2003) 161-168.

[27] T.C. Canevari, P.A. Raymundo-Pereira, R. Landers, E.V. Benvenutti, S.A.S. Machado, Talanta 116 (2013) 726-735.

[28] T.C. Canevari, J. Arguello, M.S.P. Francisco, Y. Gushikem, J. Electroanal. Chem. 609 (2007) 61-67.

[29] S. Ray, S. Vasudevan, Inorg. Chem. 42 (2003) 1711-1719.

[30] K.I. Ozoemena, T. Nyokong, Electrochim. Acta 51 (2006) 2669-2677.

[31] Z.W. Xu, G.X. Zhang, Z.Y. Cao, J.S. Zhao, H.J. Li, J. Mol. Catal. A Chem. 318 (2010) $101-105$.

[32] D.R. Tackley, G. Dent, W.E. Smith, Phys. Chem. Chem. Phys. 3 (2001) 1419-1426.

[33] A.B.P. Lever, J. Porphyr. Phthalocya. 8 (2004) 1327-1342.

[34] J.H. Zagal, S. Griveau, M. Santander-Nelli, S.G. Granados, F. Bedioui, J. Porphyr. Phthalocya. 16 (2012) 713-740.

[35] T. Mugadza, T. Nyokong, Polyhedron 30 (2011) 1820-1829.

[36] L. Alagna, A. Capobianchi, A.M. Paoletti, G. Pennesi, G. Rossi, M.P. Casaletto, A. Generosi, B. Paci, V.R. Albertini, Thin Solid Films 515 (2006) 2748-2753.

[37] J.H. Zhu, Y.X. Li, Y. Chen, J. Wang, B. Zhang, J.J. Zhang, W.J. Blau, Carbon 49 (2011) 1900-1905.

[38] R. Zhang, Y. Peng, Z. Li, K. Li, J. Ma, Y. Liao, L. Zheng, X. Zuo, D. Xia, Electrochim. Acta 147 (2014) 343-351.

[39] Y.C. Chiang, W.H. Lin, Y.C. Chang, Appl. Surf. Sci. 257 (2011) 2401-2410.

[40] M. Ebadi, C. Alexiou, A.B.P. Lever, Can. J. Chem. 79 (2001) 992-1001.

[41] M. Ebadi, A.B.P. Lever, J. Porphyr. Phthalocya. 7 (2003) 529-539. 